\title{
Analysis of User Sentiment of Twitter to RUU KUHP
}

\section{Analisis Sentimen Pengguna Twitter terhadap RUU KUHP}

\author{
Danty Welmin Y.F ${ }^{1^{*}}$, M. Rizqi Destanto ${ }^{2^{*}}$, Nawang Indah $\mathbf{C}^{3^{*}}$, Sekar Ayu $\mathbf{R}^{4 *}$, \\ Wisnu Adi $K^{5 *}$, Rani Nooraeni ${ }^{6 *}$
}

\begin{abstract}
Twitter is one of social media where its user can share many responses for a phenomenon through a tweet. This research used 5000 tweets from Twitter users in Bahasa Indonesia with keyword "RUU KUHP(Draft Law of KUHP)" from 16th of September until 22nd of September 2019. That tweets were processed using Rstudio software with sentiment analysis that is one of Text Mining methods. This research aims to classify Twitter users' responses to RUU KUHP to be negative sentiment, poisitive negative, and neutral. Also, this research also aims to know about topics' frequencies that were related to RUU KUHP through visualization with bar plot and also wordcloud. This research also aims to know words that are associated with the most frequent words. Form this research, can be known that Twitter users' responses to RUU KUHP tend to have neutral sentiment that means they did not take side between agreeing or disagreeing. From this research, also can be known about 10 most frequent words, there are kpk, tunda, dpr, pasal, kesal, jokowi, presiden, masuk, ya, and sahkan. Beside that, can be known the other words that are associated with them and also their probability.
\end{abstract}

Keyword: RUU KUHP, Twitter, Text Mining, Sentiment Analysis

\begin{abstract}
Abstrak
Twitter merupakan media sosial yang menjadi wadah penggunanya untuk saling berbagi respons atas suatu peristiwa melalui cuitan. Pada penelitian ini digunakan 5000 data cuitan pengguna Twitter berbahasa Indonesia dengan kata kunci "RUU KUHP" dalam rentang waktu 16 September s.d. 22 September 2019. Data tersebut kemudian diolah menggunakan software Rstudio dengan metode analisis sentiment yang merupakan metode dalam Text Mining. Tujuan dari penelitian ini adalah untuk mengklasifikasikan respon pengguna Twitter terhadap RUU KUHP menjadi sentimen negatif, sentimen positif, dan netral. Selain itu, juga bertujuan untuk mengetahui frekuensi topik-topik mengenai RUU KUHP yang terdapat pada cuitan pengguna Twitter melalui visualisasi diagram batang dan wordcloud. Penelitian ini juga bertujuan untuk mengetahui kata-kata yang berasosiasi dengan kata yang paling sering muncul beserta peluangnya. Dari hasil penelitian, dapat diketahui bahwa respons pengguna Twitter cenderung memiliki sentimen netral yang berarti tidak memihak antara setuju maupun tidak setuju atas revisi RUU KUHP. Dari penelitian ini juga diketahui sepuluh kata yang paling sering muncul, yakni kpk, tunda, dpr, pasal, kesal, jokowi, presiden, masuk, ya, sahkan. Selain itu, dapat diketahui juga kata-kata yang berasosiasi dengan mereka beserta peluangnya.
\end{abstract}

Kata kunci: RUU KUHP, Twitter, Text Mining, Analisis Sentimen

* Politeknik Statistika STIS

Email Adress : ${ }^{1}$ danty.martha@gmail.com, ${ }^{2}$ muhammadrizqidestanto@gmail.com, ${ }^{3}$ nawangindahc@gmail.com, ${ }^{4}$ wisnuadikusuma97@gmail.com, ${ }^{5}$ sarstis58@gmail.com, ${ }^{6}$ raninoor@stis.ac.id 


\section{Danty Welmin Y.F, M. Rizqi Destanto, Nawang Indah C, Sekar Ayu R, Wisnu Adi K, Rani Nooraeni}

\section{PENDAHULUAN}

Dengan kemajuan teknologi sekarang ini, media sosial menjadi salah satu sumber data dan informasi. Namun, kebanyakan data yang dihasilkan penuh dengan teks dan tidak terstruktur. Untuk mendapatkan informasi dari data tersebut, metode yang digunakan adalah text mining. Text Mining adalah kumpulan proses-proses penambangan seperti pengumpulan, pemrosesan, analisis, dan visualisasi guna mendapatkan informasi berharga (insight) dari text. (Mariyah, 2018) Twitter merupakan media sosial dengan 6,43 juta pengguna dan menduduki posisi keempat terbesar di Indonesia pada tahun 2019 (Kemp, 2019). Indraloka dan Santosa (2017) menyatakan bahwa pengguna Twitter dapat membuat sebuah pesan pendek yang disebut dengan tweet, dimana melalui tweet tersebut, pengguna Twitter dapat saling berhubungan, berbagi pendapat, dan menemukan kabar dari berbagai penjuru dunia. Berdasarkan data Google Trend, terjadi eskalasi pencarian mengenai RKUHP pada tanggal 18 September 2019. Hal yang sama pun terjadi di Twitter.

Kitab Undang-Undang Hukum Perdata (KUHP) adalah aturan hukum warisan kolonial Belanda yang berlaku di Indonesia berdasarkan asas konkordansi dan disahkan melalui UU Nomor 1 Tahun 1946 (Ulfah, 2016). Karena berasal dari zaman kolonial, maka aturan ini tidak sesuai untuk karakteristik masyarakat Indonesia sehingga dilakukanlah revisi (RKUHP). Namun dalam prosesnya revisi tersebut mengundang banyak kontroversi. Pasal-pasal tersebut dianggap merugikan bagi masyarakat kecil seperti yang dinyatakan Dahnil Anzar dalam akun Twitter pribadinya, Kamis (19/9/2019), "RKUHP kita dirancang untuk mempertajam hokum bagi rakyat kecil. Namun, menumpulkan hokum untuk elite, termasuk UU KPK."

Tujuan penelitian ini ialah untuk mengklasifikasikan respon pengguna Twitter terhadap RUU KUHP menjadi sentimen negatif, sentimen positif, dan netral, mengetahui frekuensi topik-topik mengenai RUU KUHP, dan mengetahui kata-kata yang berasosiasi dengan kata yang paling sering muncul dalam respon pengguna Twitter periode 16 September - 22 September 2019. Diharapkan hasil penelitian ini dapat memberikan gambaran respon pengguna Twitter mengenai RUU KUHP bagi pemerintah sebagai dasar dalam memutuskan pasal-pasal mana saja yang perlu dikaji ulang.

\section{KAJIAN PUSTAKA}

\subsection{Twitter}

Twitter adalah sebuah media sosial dan layanan microblogging yang mengijinkan penggunanya untuk mengirimkan pesan realtime (pesan ini popular dengan sebutan tweet) (Hadna dkk, 2016). Berikut ini adalah beberapa istilah yang dikenal dalam Twitter (Hadna dkk, 2016):

\section{a. Mention}

Mention adalah menyebut atau memanggil pengguna Twitter lain dalam sebuah tweet. Mention dilakukan dengan menuliskan '@' diikuti dengan nama pengguna lain.

b. Hashtag

Hashtag digunakan untuk menandai sebuah topik pembicaraan di Twitter. Penulisan hashtag dimulai dengan tanda '\#' diikuti dengan topik yang sedang dibahas. Hashtag biasa digunakan untuk meningkatkan visibilitas tweet pengguna. 


\section{Danty Welmin Y.F, M. Rizqi Destanto, Nawang Indah C, Sekar Ayu R, Wisnu Adi K, Rani Nooraeni}

\section{c. Emoticon}

Emoticon adalah ekspresi wajah yang direpresentasikan dengan kombinasi antara huruf, tanda baca dan angka. Pengguna biasa menggunakan emoticon untuk mengekspresikan mood yang sedang mereka rasakan.

d. Trending topics.

Jika hashtag adalah cara untuk menandai sebuah topik pembicaraan di Twitter, maka trending topics adalah kumpulan dari topik pembicaraan yang sangat populer di Twitter.

\subsection{Data Mining}

Data mining adalah proses yang menggunakan teknik statistik, matematika, kecerdasan buatan, dan machine learning untuk mengekstraksi dan mengidentifikasi informasi yang bermanfaat dan pengetahuan yang terkait dari berbagai database besar (Turban dkk, 2005).

\section{a. Metode Pelatihan}

Secara garis besar metode pelatihan yang digunakan dalam teknik-teknik data mining dibedakan ke dalam dua pendekatan, yaitu (Santosa, 2007) :

- Unsupervised learning, metode ini diterapkan tanpa adanya latihan (training) dan tanpa ada guru (teacher). Guru di sini adalah label dari data.

- $\quad$ Supervised learning, yaitu metode belajar dengan adanya latihan dan pelatih. Dalam pendekatan ini, untuk menemukan fungsi keputusan, fungsi pemisah atau fungsi regresi, digunakan beberapa contoh data yang mempunyai output atau label selama proses training.

\section{b. Pengelompokan Data Mining}

Ada beberapa teknik data mining berdasarkan tugas yang dapat dilakukan, yaitu (Fadli, 2003)

- Konsep/ Class Description

Data dapat diasosiasikan dengan pembagian class atau konsep. Hal tersebut sangat berguna untuk menggambarkan pembagian class secara individual dan konsep secara ringkas, laporan ringkas, dan juga pengaturan harga. Deskripsi suatu class atau konsep seperti itu disebut class/concept descripition.

- Association Analysis

Association analysis adalah penemuan association rules yang menunjukkan nilai kondisi suatu attribute yang terjadi bersama-sama secara terus-menerus dalam memberikan set data. Association analysis secara luas dipakai untuk market basket atau analisa data transaksi.

- $\quad$ Klasifikasi dan Predikasi

Klasifikasi dan prediksi mungkin perlu diproses oleh analisis relevan, yang berusaha untuk mengidentifikasi atribut-atribut yang tidak ditambahkan pada proses klasifikasi dan prediksi. Atribut-atribut ini kemudian dapat di keluarkan.

- Cluster Analysis

Tidak seperti klasifikasi dan prediksi, yang menganalisis objek data dengan kelas yang terlabeli, clustering menganalisis objek data tanpa mencari keterangan pada label kelas yang diketahui. Pada umumnya, label kelas tidak ditampilkan di dalam latihan data simply, karena mereka tidak tahu bagaimana memulainya. Clustering dapat digunakan untuk menghasilkan label-label. 


\section{Danty Welmin Y.F, M. Rizqi Destanto, Nawang Indah C, Sekar Ayu R, Wisnu Adi K, Rani Nooraeni}

\section{- Outlier Analysis}

Outlier dapat dideteksi menggunakan uji yang bersifat statistik yang mengambil sebuah distribusi atau probabilitas model untuk data, atau menggunakan langkah-langkah jarak jauh dimana objek yang penting jauh dari cluster lainnya dianggap outlier.

\section{- Evolution Analysis}

Data analisa evolusi menggambarkan ketetapan model atau kecenderungan objek yang memiliki kebiasaan berubah setiap waktu.

\section{c. Langkah - langkah Data Mining}

Langkah-langkah untuk melakukan data mining adalah sebagai berikut (Fadli, 2003) :

a. Data cleaning (untuk menghilangkan noise data yang tidak konsisten)

b. Data integration (dimana sumber data yang terpecah dapat disatukan).

c. Data selection (dimana data yang relevan dengan tugas analisis dikembalikan ke dalam database).

d. Data transformation (di mana data berubah atau bersatu menjadi bentuk yang tepat untuk menambang dengan ringkasan performa atau operasi agresi).

e. Data mining (proses esensial di mana metode yang intelejen digunakan untuk mengekstrak pola data).

f. Pattern evolution (untuk mengidentifikasi pola yang benar-benar menarik yang mewakili pengetahuan berdasarkan atas beberapa tindakan yang menarik).

g. Knowledge presentation (di mana gambaran teknik visualisasi dan pengetahuan digunakan untuk memberikan pengetahuan yang telah ditambang kepada $u s e r$ ).

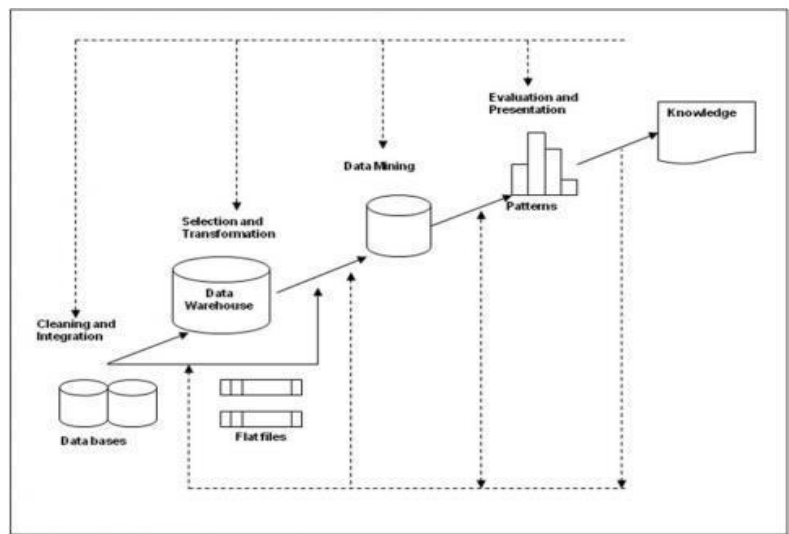

Gambar 2.1. Langkah-langkah Data Mining

\subsection{Text Mining}

Textmining adalah kumpulan proses-proses penambangan seperti pengumpulan, pemrosesan, analisis, dan visualisasi guna mendapatkan informasi berharga (insight) dari text (Mariyah, 2018).Menurut Kurniawan, dkk..(2012), langkah-langkah yang dilakukan dalam text mining adalah sebagai berikut (as cited in Karyadi, et al.., 2016)

1. Text Preprocessing

Tindakan yang dilakukan pada tahap ini adalah:

- $\quad$ To lower case, yaitu mengubah semua karakter huruf menjadi huruf kecil. 


\section{Danty Welmin Y.F, M. Rizqi Destanto, Nawang Indah C, Sekar Ayu R, Wisnu Adi K, Rani Nooraeni}

- $\quad$ Tokenizing, yaitu proses penguraian deskripsi yang semula berupa kalimat - kalimat menjadi kata-kata.

- $\quad$ Remove number, yaitu menghilangkan karakter angka yang ada pada kata tersebut.

- Remove url, yaitu menghilangkan link internet.

- Remove punctuation, yaitu menghilangkan delimiter-delimiter seperti tanda titik(.), koma(,) dan spasi.

2. Feature Selection

Pada tahap ini tindakan yang dilakukan adalah:

- $\quad$ Stopword (stopword removal) adalah kosa kata yang bukan merupakan ciri (kata unik) dari suatu dokumen. Stopword untuk bahasa Indonesia diperoleh dari: http://www.ranks.nl/stopwords/indonesian (Doyle, 2010).

- $\quad$ Stemming adalah proses pemetaan dan penguraian berbagai bentuk (variants) dari suatu kata menjadi bentuk kata dasarnya (stem).

\subsection{Sentiment Analyis}

Sentiment analysis/ analisis sentimen, juga disebut opinion mining, adalah bidang studi yang menganalisis opini, sentimen, evaluasi, penilaian, sikap, dan emosi orang terhadap entitas seperti produk, layanan, organisasi, individu, masalah, peristiwa, topik, dan atributnya (Liu, 2012). Sentiment Analysis dapat dibedakan berdasarkan sumber datanya, beberapa level yang sering digunakan dalam penelitian Sentiment Analysis adalah Sentiment Analysis pada level dokumen dan Sentiment Analysis pada level kalimat (Fink dkk, 2011). Berdasarkan level sumber datanya Sentiment Analysis terbagi menjadi 2 kelompok besar yaitu (Fink dkk, 2011): Coarse-grained Sentiment Analysis dan Fined-grained Sentiment Analysis. Pada Sentiment Analysis Coarse-grained, Sentiment Analysis yang dilakukan adalah pada level dokumen. Secara garis besar fokus utama dari Sentiment Analysis jenis ini adalah menganggap seluruh isi dokumen sebagai sebuah sentiment positif atau sentiment negatif. Fined-grained Sentiment Analysis adalah Sentiment Analysis pada level kalimat. Fokus utama Fined-grained Sentiment Analysis adalah menentukan sentimen pada setiap kalimat.

\subsection{Association Rule}

Asosiasi merupakan hubungan suatu attribute dengan attribute yang lain yang muncul bersamaan. Misalnya penjualan susu ternyata memiliki asosiasi dengan penjualan roti. (Pramana, 2018)

\section{METODOLOGI}

\subsection{Data}

Data dalam penelitian ini merupakan data yang bersumber dari Twitter. Data terdiri dari 5000 cuitan berbahasa Indonesia yang mengandung kata "RUU KUHP" yang dibagikan oleh pengguna Twitter sejak tanggal 16 September 2019 s.d. 22 September 2019. Data diambil menggunakan software Rstudio dimana perlu digunakan API key yang didapat setelah mendaftar Twitter developer.

\subsection{Metode Penelitian}




\section{Danty Welmin Y.F, M. Rizqi Destanto, Nawang Indah C, Sekar Ayu R, Wisnu Adi K, Rani Nooraeni}

Metode penelitian yang digunakan dalam penelitian ini adalah Sentiment Analysis pada TextMining. Penelitian ini menggunakan software R studio. Proses tahapan penelitian ini adalah sebagai berikut:

\section{a. Pengambilan data}

Data merupakan cuitan berbahasa Indonesia yang dibagikan oleh pengguna Twitter dan mengandung kata "RUU KUHP". Banyak cuitan yang diambil adalah sebesar 5000 cuitan. Pengambilan cuitan diperoleh menggunakan Rstudio software dimana membutuhkan API key yang didapatkan setelah mendaftar pada Twitter developer. Data yang berhasil didapatkan diubah bentuk ke dalam data frame untuk dilanjutkan proses berikutnya.

\section{b. Pre-Processing}

- Pembersihan Data

Data berupa cuitan yang sudah diperoleh dan diubah ke dalam bentuk data frame akan dibersihkan pada tahap ini. Yang dilakukan dalam pembersihan data adalah membersihkan cuitan dari kata, angka, tanda baca, dan simbol yang tidak berguna dalam cuitan. Pembersihan terhadap URL juga dilakukan terhadap cuitan yang akan dianalisis. Dalam penghapusan kata yang tidak berguna (stopwords) digunakan kamus TALA 2008.

- $\quad$ Proses Stemming, Tokenizing, dan Penghapusan Cuitan yang Berulang

Setelah data bersih dari unsur yang tidak berguna dan unsur yang perlu dihilangkan, dilakukan stemming (mengubah kata yang mengandung imbuhan menjadi kata dasar), tokenizing, dan penghapusan cuitan yang berulang. Pada tahap ini didapatkan 807 cuitan yang benar-benar bersih dan tidak terdapat adanya perulangan. Dalam proses stemming digunakan kamus katadasar oleh Nurandi.

\section{c. Analisis Sentimen}

Pada penelitian ini, analisis sentimen akan mengklasifikasikann cuitan menjadi tiga yakni sentimen positif, sentimen negatif, dan netral. Dalam tahapan ini akan digunakan sistem scoring terhadap setiap kata pada setiap cuitan untuk memperoleh klasifikasi dari cuitan tersebut. Penentuan score pada kata - kata tersebut menggunakan kamus dasar positif dan negatif. Sehingga diperoleh hasil scoring yang bisa dilihat pada tabel Skor Cuitan di bawah.

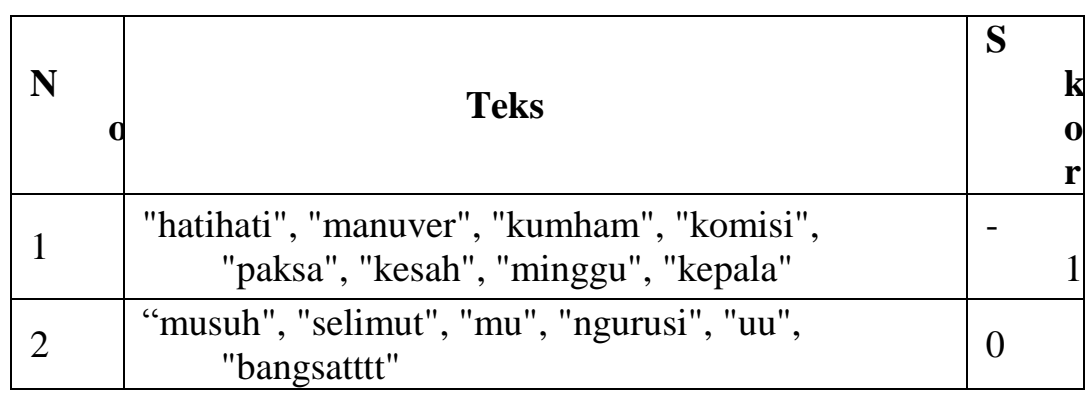




\section{Adi K, Rani Nooraeni}

\begin{tabular}{|l|l|l|}
\hline 3 & $\begin{array}{c}\text { "bilang", "jokowi", "suka", "nikam", "teman", } \\
\text { "belakangpak", "jokowi", "setia", } \\
\text { "kawan", "bukti", "bombardir", "kpk", } \\
\text { "habis" }\end{array}$ & 0 \\
\hline 4 & $\begin{array}{c}\text { "ayam", "pelihara", "masuk", "makan", } \\
\text { "kebun", "orang", "denda", "rp", "juta" }\end{array}$ & - \\
\hline 5 & $\begin{array}{c}\text { "horeee", "tunda", "terimakasih", "terima", "kasih", "mahasi\$wa", } \\
\text { "demo" }\end{array}$ & $\ldots$ \\
\hline $\mathrm{D}$ & $\mathrm{s}$ & $\ldots$ \\
\hline
\end{tabular}

Jika score bernilai positif berarti cuitan cenderung setuju terhadap RUU KUHP. Sedangkan, jika score bernilai negatif berarti cuitan cenderung tidak setuju tehadap RUU KUHP dan jika score bernilai nol berarti cuitan cenderung netral.

\section{d. Visualisasi}

Pada tahapan ini, akan dilakukan visualisai dari klasifikasi yang telah dilakukan pada tahap sebelumnya. Yang akan divisualisasi dalam tahap ini adalah klasifikasi dari sentimen. Selain itu, akan dibentuk wordcloud dan diagram batang untuk mengetahui kata apa saja yang sering digunakan pada cuitan mengenai RUU KUHP.

\section{HASIL DAN PEMBAHASAN}

\subsection{Frekuensi Kata-Kata yang Terkait dengan RUU KUHP}

Dari lima ribu cuitan yang didapatkan lewat software $\mathrm{R}$ menggunakan Application Programming Interface (API), dilakukan proses cleaning dan berhasil disaring menjadi 807 cuitan. Kemudian dari cuitan-cuitan tersebut dapat dirangkum kata-kata yang paling sering muncul seperti pada gambar wordcloud berikut.

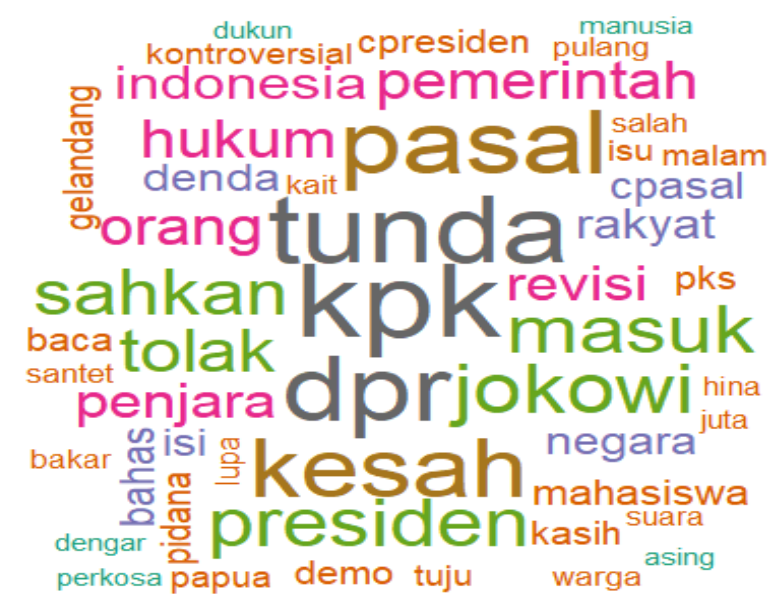

Gambar 4.1. Wordcloud dari Kata-Kata yang Muncul dengan Jumlah Terbanyak 


\section{Danty Welmin Y.F, M. Rizqi Destanto, Nawang Indah C, Sekar Ayu R, Wisnu Adi K, Rani Nooraeni}

Dengan melihat wordcloud pada gambar 4.1 dapat dilihat bahwa "kpk", "tunda", dan "dpr" merupakan kata yang paling besar jika dibandingkan dengan kata-kata yang lain. Hal ini dikarenakan dalam cuitan yang membahas RUU KUHP, banyak yang menggunakan kata-kata tersebut. Hasil wordcloud ini merupakan bentuk deskripsi yang masih umum. Untuk keterangan yang lebih rinci dapat dilihat pada tabel berikut.

Tabel 4.1. Sepuluh Kata yang Paling Sering Muncul

\begin{tabular}{|l|l|l|}
\hline No & \multicolumn{1}{|c|}{ Kata } & Frekuensi \\
\hline 1. & kpk & 84 \\
\hline 2. & tunda & 74 \\
\hline 3. & dpr & 72 \\
\hline 4. & pasal & 71 \\
\hline 5. & kesah & 65 \\
\hline 6. & jokowi & 51 \\
\hline 7. & presiden & 50 \\
\hline 8. & masuk & 48 \\
\hline 9. & ya & 48 \\
\hline 10. & sahkan & 47 \\
\hline
\end{tabular}

Tabel 4.1 sejalan dengan wordcloud, ditunjukkan dengan kata yang paling sering muncul dalam 807 cuitan adalah "kpk" dengan rincian kemunculan sebanyak 84 kali, diikuti oleh "tunda" dengan rincian kemunculan sebanyak 74 kali dan "dpr" dengan rincian kemunculan sebanyak 71 kali. Visualisasi dari tabel 4.1 dapat dilihat pada gambar 4.2.

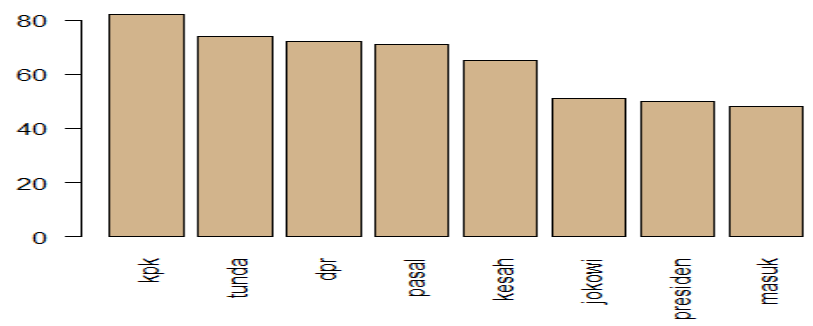

\subsection{Analisis Sentimen Respon Pengguna Twitter terhadap RUU KUHP}

Selanjutnya, respon pengguna Twitter terhadap RUU KUHP duklasifikasikan menjadi sentimen negatif, sentimen positif, dan netral.

Tabel 4.2. Frekuensi Cuitan Berdasarkan Analisis Sentimen

\begin{tabular}{|l|l|}
\hline \multicolumn{1}{|c|}{ Sentimen } & \multicolumn{1}{c|}{ Frekuensi } \\
\hline Positif & 65 \\
\hline Negatif & 347 \\
\hline Netral & 395 \\
\hline
\end{tabular}




\section{Danty Welmin Y.F, M. Rizqi Destanto, Nawang Indah C, Sekar Ayu R, Wisnu Adi K, Rani Nooraeni}

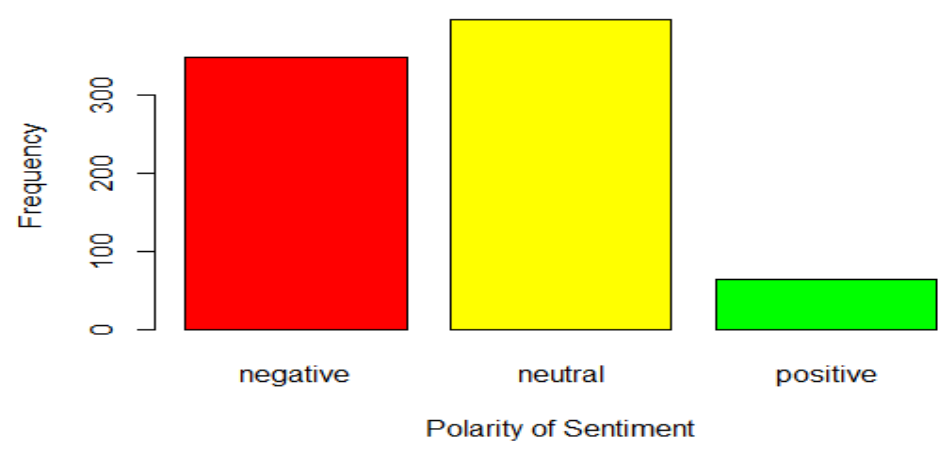

Berdasarkan diagram batang di atas, dapat disimpulkan cuitan pengguna Twitter mengenai RUU KUHP sentimen net1 Gambar 4.3. Diagram Batang Polaritas Sentimen ndung positif memiliki frekuensi paling sedikit. Frekuensi sentimen positif yang berjumlah 65 jauh lebih kecil dibandingkan sentiment negatif dan netral dengan jumlah masing-masing 347 dan 395 . Hanya 8,05\% cuitan yang mengandung sentimen positif terkait RUU KUHP. Hal ini berarti, mayoritas masyarakat pengguna Twitter yang sebesar 395 orang membagikan cuitan dengan sentimen netral. Dimana hal itu berarti, mayoritas pengguna Twitter yang membagikan cuitan mengenai RUU KUHP cenderung netral, tidak berpihak baik setuju maupun tidak setuju. Sedangkan 347 orang cenderung membagikan cuitan dengan sentimen negatif, hal tersebut berarti sebanyak 347 orang yang membagikan cuitan tentang RUU KUHP, cenderung tidak

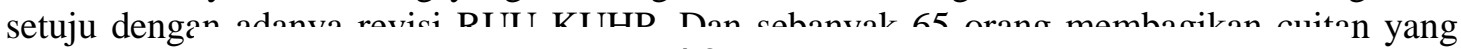
mengandung Tabel 4.3. Summary Score cuitan tentang RUU KUHP, mendukung adanya revisi RUU KUHP.

\begin{tabular}{|c|c|}
\hline Maksimum & 2 \\
\hline \multicolumn{2}{|c|}{ Tabel 4.3. Summary Score } \\
\hline lviean & - \\
\hline Varians & 1,106192 \\
\hline
\end{tabular}

Berdasarkan tabel 4.3 terlihat bahwa rata-rata skor cuitan tentang RUU KUHP bernilai sebesar -0.5873606 artinya cuitan mengenai RUU KUHP cenderung memiliki sentimen negatif dengan nilai minimum -5 dan maksimum 2. Varians bernilai 1,106192 yang berarti data kurang bervariasi atau cenderung homogen. Hal ini menunjukan bahwa cuitan-cuitan tersebut memiliki kecenderungan berpendapat negatif terhadap RUU KUHP.

\subsection{Asosiasi Kata yang Paling Sering Muncul dalam Respon Pengguna Twitter Terkait RUU KUHP}




\section{Danty Welmin Y.F, M. Rizqi Destanto, Nawang Indah C, Sekar Ayu R, Wisnu Adi K, Rani Nooraeni}

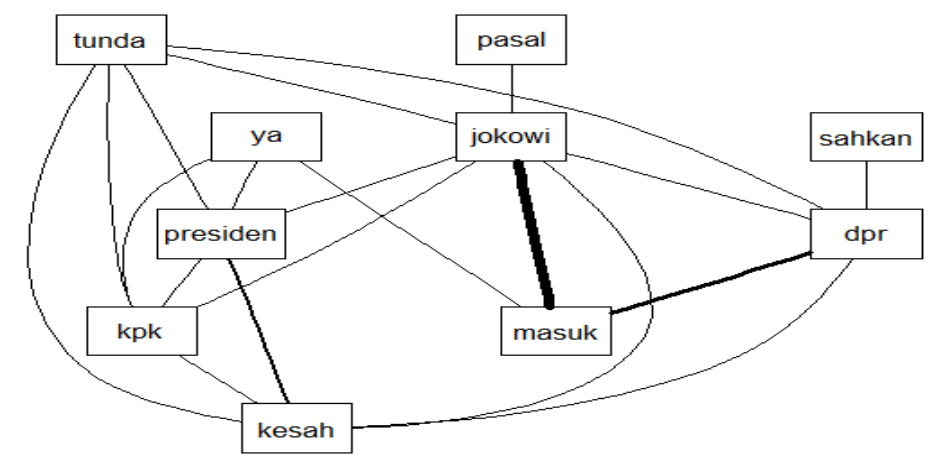

Dari gambar 4.4, asosiasi antarkata dapat dilihat melalui kata-kata yang dihubungkan oleh garis. Dua kata dengan garis penghubung yang lebih tebal memiliki asosiasi yang bersifat lebih kuat dibandingkan dengan garis penghubung yang lebih tipis. Sehingga dapat diketahui bahwa kata yang memiliki asosiasi paling kuat adalah "jokowi" dengan "masuk". Diikuti oleh kata 'masuk'

Gambar 4.4. Asosiasi untuk Kata yang Paling Sering Muncul

Peluang kata-kata yang berasosiasi dengan 10 kata yang paling sering muncul dapat dilihat pada table-tabel di bawah ini.

\section{a. Kata-kata yang Berasosiasi dengan Kata "kpk"}

Tabel 4.4. Peluang Kata yang Muncul saat Kata "kpk" juga Muncul

\begin{tabular}{|l|l|}
\hline \multicolumn{1}{|c|}{ Kata } & Peluang Kata Muncul saat Kata "kpk" juga Muncul \\
\hline uu & 0,47 \\
\hline papua & 0,38 \\
\hline revisi & 0,30 \\
\hline alih & 0,27 \\
\hline beda & 0,23 \\
\hline ubah & 0,22 \\
\hline aspirasi & 0,22 \\
\hline jaring & 0,22 \\
\hline karhutla & 0,21 \\
\hline restu & 0,21 \\
\hline lemah & 0,20 \\
\hline rasisme & 0,20 \\
\hline
\end{tabular}

\section{b. Kata-kata yang Berasosiasi dengan Kata "tunda"}

Tabel 4.5. Peluang Kata yang Muncul saat Kata "tunda" juga Muncul

\begin{tabular}{|c|c|}
\hline Kata & $\begin{array}{c}\text { Peluang Kata Muncul saat Kata "tunda" juga } \\
\text { Muncul }\end{array}$ \\
\hline kesah & 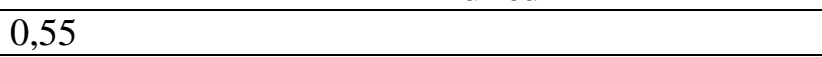 \\
\hline presiden & 0,42 \\
\hline jokowi & 0,36 \\
\hline
\end{tabular}


Danty Welmin Y.F, M. Rizqi Destanto, Nawang Indah C, Sekar Ayu R, Wisnu Adi K, Rani Nooraeni

c. Kata-kata yang Berasosiasi dengan Kata "dpr”

Tabel 4.6. Peluang Kata yang Muncul saat Kata “dpr” juga Muncul

\begin{tabular}{|l|l|}
\hline \multicolumn{1}{|c|}{ Kata } & Peluang Kata Muncul saat Kata “dpr" juga Muncul \\
\hline anggota & 0,36 \\
\hline becus & 0,23 \\
\hline surati & 0,23 \\
\hline mulan & 0,22 \\
\hline kerok & 0,22 \\
\hline pesan & 0,22 \\
\hline tugas & 0,22 \\
\hline kesah & 0,21 \\
\hline ketua & 0,21 \\
\hline
\end{tabular}

d. Kata-kata yang Berasosiasi dengan Kata "pasal"

Tabel 4.7. Peluang Kata yang Muncul saat Kata "pasal” juga Muncul

\begin{tabular}{|l|l|}
\hline \multicolumn{1}{|c|}{ Kata } & Peluang Kata Muncul saat Kata “pasal” juga Muncul \\
\hline media & 0,25 \\
\hline hina & 0,24 \\
\hline ayat & 0,24 \\
\hline
\end{tabular}

e. Kata-kata yang Berasosiasi dengan Kata "kesah"

Tabel 4.8. Peluang Kata yang Muncul saat Kata "kesah" juga Muncul

\begin{tabular}{|l|l|}
\hline \multicolumn{1}{|c|}{ Kata } & \multicolumn{1}{|c|}{ Peluang Kata Muncul saat Kata “kesah" juga } \\
Muncul
\end{tabular}

\section{f. Kata-kata yang Berasosiasi dengan Kata "jokowi”}

Tabel 4.9. Peluang Kata yang Muncul saat Kata “jokowi” juga Muncul

\begin{tabular}{|l|l|}
\hline \multicolumn{1}{|c|}{ Kata } & \multicolumn{1}{|c|}{ Peluang Kata Muncul saat Kata “jokowi" juga } \\
Muncul
\end{tabular}


Danty Welmin Y.F, M. Rizqi Destanto, Nawang Indah C, Sekar Ayu R, Wisnu

Adi K, Rani Nooraeni

\begin{tabular}{|l|l|}
\hline setia & 0,36 \\
\hline tunda & 0,36 \\
\hline aneh & 0,32 \\
\hline presiden & 0,31 \\
\hline kesah & 0,30 \\
\hline kawan & 0,29 \\
\hline teman & 0,29 \\
\hline
\end{tabular}

g. Kata-kata yang Berasosiasi dengan Kata "presiden"

Tabel 4.10. Peluang Kata yang Muncul saat Kata “presiden” juga Muncul

\begin{tabular}{|c|c|}
\hline Kata & $\begin{array}{c}\text { Peluang Kata Muncul saat Kata "presiden" juga } \\
\text { Muncul }\end{array}$ \\
\hline jadwal & 0,36 \\
\hline kampanye & 0,36 \\
\hline sinyal & 0,27 \\
\hline pdip & 0,25 \\
\hline restu & 0,25 \\
\hline hina & 0,23 \\
\hline tuju & 0,22 \\
\hline
\end{tabular}

\section{h. Kata-kata yang Berasosiasi dengan Kata "masuk"}

Tabel 4.11. Peluang Kata yang Muncul saat Kata "masuk" juga Muncul

\begin{tabular}{|c|c|}
\hline Kata & $\begin{array}{c}\text { Peluang Kata Muncul saat Kata "masuk" juga } \\
\text { Muncul }\end{array}$ \\
\hline giat & 0,40 \\
\hline ayam & 0,30 \\
\hline eksploitasi & 0,26 \\
\hline jenis & 0,26 \\
\hline kebun & 0,26 \\
\hline pelihara & 0,25 \\
\hline pemerkosaan & 0,25 \\
\hline dukun & 0,23 \\
\hline santet & 0,23 \\
\hline bukti & 0,23 \\
\hline kalangan & 0,20 \\
\hline
\end{tabular}

i. Kata-kata yang Berasosiasi dengan Kata "ya"

Tabel 4.12. Peluang Kata yang Muncul saat Kata "ya” juga Muncul

\begin{tabular}{|l|l|}
\hline \multicolumn{1}{|c|}{ Kata } & Peluang Kata Muncul saat Kata “ya” juga Muncul \\
\hline kali & 0,32 \\
\hline goblok & 0,30 \\
\hline
\end{tabular}


Danty Welmin Y.F, M. Rizqi Destanto, Nawang Indah C, Sekar Ayu R, Wisnu Adi K, Rani Nooraeni

\begin{tabular}{|l|l|}
\hline kecap & 0,28 \\
\hline stok & 0,28 \\
\hline lucu & 0,24 \\
\hline kau & 0,20 \\
\hline
\end{tabular}

j. Kata-kata yang Berasosiasi dengan Kata "sahkan"

Tabel 4.13. Peluang Kata yang Muncul saat Kata "sahkan” juga Muncul

\begin{tabular}{|l|l|}
\hline \multicolumn{1}{|c|}{ Kata } & \multicolumn{1}{|c|}{ Peluang Kata Muncul saat Kata "sahkan" juga } \\
Muncul
\end{tabular}

\section{KESIMPULAN}

Dari 5000 data cuitan dengan kata kunci "RUU KUHP" dari tanggal 16 September 2019 sampai dengan 22 September 2019 yang dibagikan oleh penggunan Twitter dan telah melalui proses cleaning, didapatkan 807 cuitan yang benar-benar siap olah. Dari 807 cuitan, dapat diketahui bahwa masyarkat yang membagikan cuitan tentang RUU KUHP cenderung memiliki sentimen netral pada cuitannya. Hal ini berarti, mereka tidak mendukung maupun mendukung revisi RUU KUHP. Dari hasil pengolahan juga didapatkan 10 kata yang paling sering muncul seperti kpk, tunda, dpr, pasal, kesal, jokowi, presiden, masuk, ya, sahkan.

\section{DAFTAR PUSTAKA}

[1] Fadli, A. (2003). Konsep Data Mining. Ilmu Komputer.

[2] Fink, C. R., Chou, D. S., Kopecky, J. J., \& Llorens, A. J. (2011). Coarse- and FineGrained Sentiment Analysis of Social Media Text. Johns hopkins apl technical digest, 30(1), 22-30.

[3] Hadi, A. F., C. W., D. B., \& Hasan, M. (2017). Text Mining pada Media Sosial Twitter Studi Kasus: Masa Tenang Pilkada DKI 2017 Putaran 2. Seminar Nasional Matematika dan Aplikasinya (hal. 324-331). Surabaya: Universitas Airlangga.

[4] Hadna, N. M. S., Santosa, P. I., \& Winarno, W. W. (2016). Studi Literatur Tentang Perbandingan Metode untuk Proses Analisis Sentimen di Twitter. Semin. Nas. Teknol. Inf. dan Komun, 2016, 57-64. 
Danty Welmin Y.F, M. Rizqi Destanto, Nawang Indah C, Sekar Ayu R, Wisnu Adi K, Rani Nooraeni

[5] Hidayatullah, A. F., \& SN, A. (2014). Analisis Sentimen dan Klasifikasi Kategori Terhadap Tokoh Publik pada Twitter. Seminar Nasional Informatika (hal. 115122). Yogyakarta: UPN "Veteran" Yogyakarta.

[6] Indraloka, D. S., \& Santosa, B. (2017). Penerapan Text Mining untuk Melakukan Clustering Data Tweet Shopee Indonesia. JURNAL SAINS DAN SENI ITS, 6, A51-A56.

[7] Karyadi, S., Yasin, H., \& Mukid, M. A. (2016). Analisis Kecenderungan Informasi Dengan Menggunakan Metode Text Mining (Studi Kasus: Akun Twitter @ detikcom). Jurnal Gaussian, 5, 763-770.

[8] Kemp, S. (2019, January 31). Digital 2019: Indonesia. Dipetik September 27, 2019, dari Data Reportal: https://datareportal.com/reports/digital-2019-indonesia

[9] Liu, B. (2012). Sentiment analysis and opinion mining. Synthesis lectures on human language technologies, 5(1), 1-167.

[10] Pramana S., Yuniarto B., Mariyah S., Santoso, I., dan Nooraeni R. 2018. Data Mining dengan R Konsep Serta Implementasi. Jakarta : InMedia.

[11] Ridwan, M., Suyono, H., \& Sarosa, M. (2013). Penerapan Data Mining Untuk Evaluasi Kinerja Akademik Mahasiswa Menggunakan Algoritma Naive Bayes Classifier. Jurnal EECCIS, 7(1), 59-64.

[12] Ulfah, E. N. (2016). URGENSI PEMBARUAN KITAB UNDANG-UNDANG HUKUM PIDANA :ANALISIS KAJIAN PERKARA NO 46/PUU-XIV/2016. Indonesian Journal of Criminal Law Studies, 72-86. 